Світлана Мангура

ORCID: https://orcid.org/0000-0002-7017-7317

Яна Руденко

ORCID: https://orcid.org/0000-0002-0215-5589

DOI 10.31558/1815-3070.2020.40.2.13

УДК 811.111’25:622.276

\title{
ОСОБЛИВОСТІ ПЕРЕКЛАДУ АНГЛОМОВНИХ ТЕХНІЧНИХ ТЕРМІНІВ УКРАЇНСЫКОЮ МОВОЮ (НА МАТЕРІАЛІ ТЕРМІНОЛОГІЇ НАФТОГАЗОВОЇ ГАЛУЗІ)
}

Розглянуто особливості перекладу англомовних термінів нафтогазової тематики. Увага при изьому звертається на стиль і жанр технічного тексту. Проаналізовано основні труднощі перекладу зазначеної термінології. Проведене авторами дослідження показало, що переклад текстів нафтогазової тематики вимагає спеціальної вузькоспрямованої підготовки, глибоких знань рідної та іноземної мов. У роботі розглянуті приклади слів та словосполучень, щзо мають у загальномовному плані одне значення, але змінюють його у вузькопрофільному сенсі, особливо в поєднанні з іншими словами.

Ключові слова: термінологія, нафтогазова галузь, перекладач, мова, переклад, спеціальна лексика, знання, особливості.

Актуальність дослідження обумовлено появою все більшої кількості нових тер мінів, які утворилися завдяки науково-технічному прогресу, що стр імко набирає обертів. Видається цікавим вивчення термінології в нафтогазовій галузі, оскільки нафта і газ вважаються головними енергоносіями в сучасному світі, відіграють важливу роль у торгових відносинах між державами. Ця вир обнича сфера динамічно розвивається, що передусім позначається на життєзабезпеченні людини. Крім того, вивчення нафтогазової тер мінології розширює концептуальний апарат цієї галузі наукового знання.

Будь-який професійний перекладач стикається із необхідністю перекладу спеціальних тер мінів 3 певного напряму або роду діяльності, йому доводиться вирішувати проблему розуміння сенсу таких вузькопрофесійних текстів. Для того щоб здійснити грамотний і найбільш точний переклад, треба знати осно вну специфіку перекладу термінів. Пропонована робота присвячена допомогти із безлічі значень будь-якого поняття знайти найбільш близький до основного тер міна мови перекладу еквівалент в початковій мові.

Науково-технічні тексти виявляють цілий ряд граматичних, лексичних і стилістичних особливостей, що становлять особливу складність для пер екл адача, оскільки ці тексти розраховані, переважно на певні професійні гр упи, які опанували специфічні екстралінгвістичні знання, i, отже, вимагають особливо ретельного аналізу.

Багато характеристик науково-технічного стилю наявні як у науково-технічних матеріалах українською, так і англійською мовою.

Проблема перекладу термінології залишається особливо актуальною в наші дні науково-технічного буму, зокрема у сфері технічного перекладу. Правильний 
перекладтехнічних тер мінів є одним із найважливіших аспектів будь-якого перекладацького проєкту. Сучасні компанії, що працюють на міжнародному рівні, розуміють, що узгодженість термінів лежить в основі розуміння сенсу, i серйозно займаються термінологічної роботою, уточнюючи терміни, які можуть пр извести до непорозумінь. Вони розробляють спеціальні термінологічні бази даних, що містять не тільки вузькопрофільну термінологію, специфічну для певної галузі, але і тер мінологію, яка не є загальноприйнятою (Карабан 125-128).

Останнім часом термінологічна робота здійснюється в широких масштабах, проте донині немає точних відповідей на ряд ключових питань, особливості перекладу термінів - одне з них.

Одним із найскладніших напрямів технічного перекладу з погляду вузькоспеціальної тер мінології є нафтогазова. Нафтогазова галузь є важливою в укр аїнській економіці. Від перекладача технічних текстів нафтогазової тематики потрібне розуміння специфіки термінології і в англійському, і в українському вар іантах. Він повинен не просто добре знати обидві мови, але і добре розбиратися у предметі. До того ж, нафтогазовий сектор поєднує в собі масу технологій з найрізноманітніших галузей знань, таких як-от інженерна справа, хімія, геологія, страхування, бухгалтерія тощо. Перекладачеві варто бути вдвічі уважнішим і ніколи не легковажити доступними довідковими матеріалами (Каткова187-190).

Загалом і в англійській, і в українській мовах в усіх текстах цього типу, як зазначає В. Н. Комісаров (Комиссаров 85-87), знаходимо пер еважне використання науково-технічної термінології. Термінами В. Н. Комісаров називає слова і словосполучення, що позначають специфічні об ' єкти і поняття, якими опер ують фахівці певної галузі науки чи техніки.

А. А. Рефор матський (Реформатский 136) визначає тер міни «як однозначні слова, позбавлені експресивності». С. В. Грінев (Гринев-Гриневич 29) характеризує термін «як спеціальну номінативну лексичну одиницю (слово або слово сполучення) спеціальної мови, прийняту для точного найменування спеціальних понять».

У період бурхливого розвитку науки багато термінів стали проникати в загальнолітературну мову і стали відомі навіть нефахівцям. Як зазначає А. А. Мірошниченко (Мирошниченко 14-15), вони стали називатися загальнонауковими термінами, які використовуються в різних галузях знань і належать науковому стилю мовлення загалом: експеримент, адекватний, еквівалент, прогнозувати, гіпотетичний, прогресувати, реакція тощо.

Мета даної роботи - висвітлити деякі аспекти функціонування лексики в контексті перекладу нафтогазової термінології і способи термінологізації в цій сфері, а також розглянути численні приклади слів, які мають у загальномовному плані одне значення, але змінюють його у вузькопрофільному сенсі, осо бливо в поєднанні з іншими словами.

Щоб досягти адекватності під час перекладу термінів, важливо зр озуміти взаємозв’язок терміна і тексту, ба більше, потрібно розуміти й ситуацію використання структурних та семантичних типів термінів. Також необхідно знати основні способи перекладу (Сухенко 3-5). Перекладач, перед тим як розпочати 
переклад тексту з нафтогазової галузі, повинен отримати необхідні знання пр о нафтогазову промисловість для більш точного пошуку еквівалента в мові пер екладу, вміти вибрати відповідний до ситуації. Дуже важливо звертатися до пер екладацьких трансформацій в разі відсутності еквівалента в мові перекладу.

Отже, перекладач нафтогазової галузі потребує детального знання не тіл ьки іноземної мови, а також методів і принципів науково-технічного пер екладу, і бути поінформованим про роботу цієї галузі виробництва.

На жаль, еквіваленти термінів не завжди існують, найчастіше в перекладі термінів використовують такі трансформації:

- описовий переклад або експлікація - найзручніший спосіб пояснення незрозумілого терміна, єдиний недолік - громіздкість і багатослівність;

- транслітерація - переклад через відтворення графічної форми за допомогою букв мови перекладу. Але це - рідкісний випадок, саме внаслідок такого способу з'явилися «помилкові друзі» перекладача, такі як contribution, data, decade, instance, simulation, etc, що грубо спотворюють зміст тексту;

- калькування - переклад тер мінів через їхнє точне відтвор ення засобами української мови, а точніше - дослівний переклад.

Можуть виникнути складнощі і з перекладом звичайних слів, які у підсу мку можуть виявитися спеціалізованими термінами:

1) слів з анімалістичним і рослинним значеннями: wildcat- пошуково-розвідувальна свердловина; Christmas tree - фонтанна арматура (споруда 3 тр уб і клапанів, яка встановлюється в гирлі свердловини для регулювання потоку наф ти або газу для запобігання викидам);

2) жаргонізмів: sinker - нерентабельна нафтова свердловина 3 пр ибутком, що швидко падає тощо;

3) слів із певною кольоровою і «смаковою» символікою: sweet crude oil «солодка» нафта 3 низьким вмістом сірки, менш ніж 0,5 \% за масою; white oil products - світлі нафтопродукти - бензин, нафта, гас тощо.

Перспективним напрямом дослідження ми вважаємо подальше вивчення прийомів і способів перекладу технічних текстів і виявлення способів утворення нових термінів у нафтогазовій галузі.

Підкреслимо, що один термін може абсолютно по-різному пер екладатися залежно від контексту, у нашому разі - галузі. Англійське слово risers, яке в повсякденному слововживанні означає «трибуни на стадіоні», в контексті на фтогазового тексту перекладається як «водовіддільна колона (райзер)». Аналогічно, слово extremities, в побуті «кінцівки», у нафтогазовій галузі означає довжину трубопроводу. Слово farm-in не має ніякого відношення до сільського господарства, а означає «договір про отримання частки участі» в освоєнні і розробці р одовища. Також і словосполучення back-infarm-out означає «реверсивна суборенда», у рамках якої «пасивна» участь орендодавця «активізується» внаслідок настання певних умов; хоча в словниках загальновживаної лексики ці слова пере кладаються «початок руху з сальто назад» і «орендована ділянка» відповідно. Неважко здогадатися, наскільки важливим є точний переклад технічних тер мінів, особливо коли йдеться про багатомільйонні контракти (Бреус 3-28). 
Наведемо низку прикладів термінів, які в нафтогазовій сфері можуть набувати зовсім інших значень: CAP (кепка, шапка) gas cap: газова шапка; batch (випічка): партія нафти, що прокачується нафтопроводом); bottom (дно), hole (діра), letter (лист): bottom hole letter contribution: сума, що сплачується підряднику після досягнення свердловиною певної глибини); cracked (розтрісканий, крекінговий): глибока переробка (на відміну від прямогонного), крекінг: $є$ продуктом крекінгу - наприклад, крекінг-газ, крекінг-мазут; deposit (депозит): ро довище; scout (розвідник): особа, наймана нафтовою компанією для збору інформації результатів пошуково-розвідувальних робіт компаній конкурентів; lifting (підйом, ліфтинг): видобуток (відбір) нафти та ін. (Хатруков).

Багато елементів бурової установки і супутні їм об' єкти мають назви, по в'язані з назвами тварин, наприклад: doghouse, в цьому разі йдеться не пр о собачу будку (як міг би перекласти непр офесійний перекладач), а про вагончик бурового майстра; майданчик для верхового робітника прийнято називати monkey board, хоча мавпи тут, зрозуміло, ні до чого. Термін mousehole також може спантеличити недосвідченого перекладача. А він означає «неглибокий отвір під підлогою бурової вишки, в якому тимчасово зберігаються ведуча бурильна тр уба і стояки труб під час нарощування бурильної колони». А, наприклад, термін pig це, звичайно, не «порося», а так звана «металева паця», яка застосовується для очищення стінок труб, що вставляється всередину трубопроводу іїі несе внутрішнім потоком нафти або газу. Щодо «кролика» (rabbit), то в нафтогазовому контексті це слово перекладається як «скребок для чищення трубопроводу», «баран» (ram) - це «плашка» (запірний елемент противикидного пр евент ора), а «дика кішка (wildcat) - «пошуково-розвідувальна свердловина». Термін go devil насправді теж означає звичайний скребок для чищення нафтових трубопроводів. Вираз graveyard tour означає нічну зміну на буровій. Нарешті, thief - це не злодюжка, а резер вуарний пробовідбірник, а термін stripper не має ніякого відношення до танцівниці кабаре і перекладається просто як «виснажена свер дловина». Останні кілька прикладів $є$ жаргонізмами, які у величезній кількості проникають в будь-яку професійну галузь (Мангура 96-97).

Для визначення терміна «нафта» також існує безліч слів. Hot oil (гар яча): нафта, що видобувається з перевищенням обмежень, встановлених владою штату (в США), або вивозиться в інші штати як порушення федеральних правил; marginal oil (маргінальний): «критична» нафта, переробка якої необхідна для заповнення пропозиції найбільш дефіцитного нафтопродукту; new oil (нова): нафта родовищ, виявлених або введених в експлуатацію після певної дати; white oil products (білий): світлі нафтопродукти - бензин, нафта та ін.; black oil (чорна): низькосортний мастильний матеріал, який використовується в тих охідних машинах; sour oil (кисла): «кисла» нафта з високим вмістом сірки, не менш ніж 0,5\%; sweet oil (солодка): «солодка» нафта з низьким вмістом сір ки, менш ніж 0,5\%; stove oil (піч): рідке паливо, википає за температури у 250-350 градуciв; skunk oil (скунс, негідник): високосірчиста нафта; run oil (бігти): нафта, що перекачується трубопроводом; preferential oil (користується перевагою): «пр еференційна» нафта, що видобувається і купується на пільгових умовах; rock oil 
(скеля): «гірське масло»-термін, що використовувався для позначення нафти в період становлення нафтової промисловості в другій половині XIX ст.

Неточності у перекладі можуть призвести до серйозних наслідків: псування устаткування, аварій, травм на виробництві. Потрібно неодмінно звертати увагу на багатозначність термінів (Татаринов 85-89).

Наприклад, термін engine належить до газової галузі, означає «двигун», «машина». Або oil - «мастило», «масло»і «нафта». Через багатозначності тер мінів виникають труднощі для технічного перекладача.

Також треба пам'ятати: перед початком перекладу текст необхідно повністю зрозуміти, усвідомити його зміст і суть. Спочатку перекладач не $\epsilon$ перекл адачем, він - лише читач, який повинен зрозуміти текст як native speaker (носій мови), тому він повинен знати усі особливості мови, що вивчається (стилістика, лексика, граматика) і знаннями в області певної науки (Сухенко 93).

Водночас цілий ряд особливостей нафтогазових матеріалів українською мовою пов' язаний зі специфічними структурами цієї мови і виділяється завдяки своєрідному використанню таких структур, порівняно з іншими стилями української мови.

Але все ж основні труднощі під час перекладу викликають галузеві тер міни, які використовуються в одній галузі знань, або вузькоспеціальні, характерні для будь-якого напряму певної галузі. Наприклад, в нафтогазовій галузі це: каптаж, дроселювання, коксовик, вертлюг. У цих приватних термінологічних системах концентрується квінтесенція кожної науки, галузі або виду діяльності.

Тексти нафтогазової тематики є одними з найскладніших щодо пер екладу вузькоспеціальної лексики, оскільки термінологія підмови видобутку нафти і газу відбиває систему понять, якими оперують ії численні галузі. Е. Ш. Думітру у своїй дисертації зазначає, що ядром цієї системи є терміни тематичної групи «Буріння свердловини. Техніка і технологія буріння», а в перехідну і в пер иферійну зони системи входять терміни інших наук і галузей знань, які $\epsilon$ невід' $є$ мною частиною термінології видобутку нафти (так звані запозичені терміни) (Думитру 15).

Тексти нафтогазової тематики є одними з найскладніших щодо перекладу вузькоспеціальної лексики, оскільки термінологія підмови видобутку нафти і газу відбиває систему понять, якими оперують ії численні галузі. Наведені пр иклади говорять про те, наскільки важливим для технічного перекладача є високий рівень професіоналізму, як важливо вивчати спеціальну літер атуру і якісні довідкові матеріали, які постійно оновлюються, щоб точно перекладати техніч ні терміни англійської мови.

Отже, під час перекладу текстів нафтогазової тематики можуть виникати такі труднощі:

1. Багатозначність. Тільки опанувавши знання в галузі нафтогазової пр омисловості, можна вибрати необхідний варіант перекладу терміна серед безлічі інших.

2. Багатокомпонентність. Кожен тер мін може бути або однокомпонентним, або багатокомпонентним. У процесі роботи з текстом необхідно перевіряти переклад поняття окремо і в поєднанні з сусіднім словом. 
3. Незнання термінології українською мовою. Перекладач може знайти відповідний переклад терміна українською мовою, але не знатиме його точного значення. У таких ситуаціях також знадобляться знання в галузі нафтогазової промисловості.

4. Реалії. Назви, їхній переклад необхідно обов'язково перевіряти, оскільки вони здебільшого вже мають свій переклад на різних мовах.

Зазначені у статті труднощі перекладу термінів, роз'яснення, якїх долати, повинні допомогти перекладачеві у досягненні точності, адекватності пер екл аду, в мінімізації помилок. Для цього треба також звертати увагу на основні сп особи перекладу, знати специфіку галузі. Загалом нафтогазовий сектор поєднує у собі масу технологій із різних галузей знань, таких як-от інженерна спр ава, х імія, геологія, страхування, бухгалтерія тощо. Цю термінологію теж потрібно знати. Ба більше, з появою нових технологій, обладнання, напрямів діяльності нафтогазові компанії часто розробляють власну термінологію, у якій також необхідно бути обізнаним.

\section{Література}

1. Бреус Е. В. Основы теории и практики перевода с русского языка на английский: учеб. пособ. Москва: УРАО, 2004. 208 с.

2. Гринев-Гриневич С. В. Терминоведение: учеб. пособ. Москва: Издательский центр «Академия», 2008. 307 с.

3. Думитру Е. Ш. Структурно-семантический анализ русской терминологии нефтедобычи: дис. ... канд. филол. наук. Москва, 2003. 120 с.

4. Ефремов А. А. Когнитивные и структурно-семантические особенности метафорических терминов (на материале терминологии американской нефтегазовой отрасли): автореф. дис. ... канд. филол. наук. Майкоп, 2013. 28 с.

5. Карабан В. І. Переклад англійської наукової і технічної літератури: посіб. Вінниця: Нова книга. 2002. 564 с.

6. Каткова С. В. Мультимедийные программы обучения иностранным языкам в высшей школе. Вестник КИГИТ. 2006. № 1. С. 125-128.

7. Каткова С. В. Формирование навыков самостоятельной работы студентов при обучении профессионально-ориентированному иностранному языку в вузе. Молодежь и наука: сб. материалов VIII Всерос. научно-технич. конф., посвященной 155-летию со дня рождения К. Э. Циолковского. 2012. С. 187-190.

8. Комиссаров В. Н. Теория перевода (лингвистические аспекты): учеб. Москва: Высшая школа, 1990. $253 \mathrm{c}$.

9. Мангура С. І. Деякі особливості перекладу англомовної нафтогазової термінології українською мовою. Інновачійні технологї у контексті іншомовної підготовки фахівия: Матеріали II Всеукраӥнської науково-практичної інтернет-конферениї. 2 квітня 2015. Полтава, 2015. С. 95-98.

10. Мирошниченко А. А. Деловое общение: учеб.-метод. комплекс. Москва: МИЭМП, 2008. $86 \mathrm{c}$.

11. Реформатский А. А. Введение в языковедение: учеб. Москва: Аспект-Пресс, 2001. 536 с.

12. Сухенко К. М. Лексичні проблеми перекладу: посіб. Київ: Вид-во Київ. ун-ту. 2000. $124 \mathrm{c}$.

13. Татаринов В. А. Теория терминоведения: в 3-х т. Т. 1. Теория термина: история и современное состояние: учеб. Москва: Моск. Лицей, 2000. 311 с.

14. Хатруков Е. М. Англо-русский словарь по нефтяному бизнесу. Москва: «Олимп-Бизнес», 2008. $400 \mathrm{c}$. 


\section{References}

1. Breus, E. Osnovy teorii i praktiki perevoda s russkogo yazyka na anglijskij: (Fundamentals of the theory and practice of translation from Russian into English). Moskva: URAO, 2004. Print.

2. Grinev-Grinevich, S. Terminovedenie (Terminological Studies). Moskva: Izdatel'skij centr "Akademiya", 2008. Print.

3. Dumitru, E. "Strukturno-semanticheskij analiz russkoj terminologii neftedobychi (Structural and Semantic Analysis of Russian Oil Production Terminology)". Diss. Moskva, 2003. Abstract. Print.

4. Efremov, A. "Kognitivnye i strukturno-semanticheskie osobennosti metaforicheskih terminov (na materiale terminologii amerikanskoj neftegazovoj otrasli)" (Cognitive and Structural and Semantic Peculiarities of Metaphorical Terms (based on the Terminology of the American Oil and Gas industry)). Diss.Majkop, 2013. Abstract. Print.

5. Karaban, V. Pereklad anglijs 'koï naukovoï i tekhnichnoï literaturi (Translation of English scientific and technical literature). Vinnicya: Nova knyha, 2002. Print.

6. Katkova, S. "Mul'timedijnye programmy obucheniya inostrannym yazykam v vysshej shkole (Multimedia Programs for Teaching Foreign Languages in Higher Education)". Vestnik KIGIT (Bulletin of KIGIT). 1 (2006): 125-128. Print.

7. Katkova, S. "Formirovanie navykov samostoyatel'noj raboty studentov pri obuchenii professional'no-orientirovannomu inostrannomu yazyku v vuze (Formation of Students' Self-study Work Skills in Teaching a Professionally Oriented Foreign Language at the University)". Molodezh' $i$ nauka: sb. materialov VIII Vseros. nauchno-tekhnich. konf., posvyashchennoj 155-letiyu so dnya rozhdeniya K. E. Ciolkovskogo. (Youth and Science: Materials of the VIII Vseros. Scientific and Technical Conf., dedicated to the 155th Anniversary of the Birth of K. E. Tsiolkovsky). (2012): 187-190. Print.

8. Komissarov, V. Teoriya perevoda (lingvisticheskie aspekty) (Translation Theory (Linguistic Aspects)). Moskva: Vysshaya shkola, 1990. Print.

9. Mangura, S. "Deyaki osoblivosti perekladu anglomovnoï naftogazovoï terminologiï ukraïns'koyu movoyu (Some Peculiarities of Translating English Oil and Gas Terminology into Ukrainian)". Innovacijni tekhnologii u konteksti inshomovnoï pidgotovki fahivcya: Materiali II Vseukraïns'koï naukovo-praktichnö̈ internet-konferenciï. 2 kvitnya 2015 (Innovative Technologies in the context of Foreign Language Training: Proceedings of the II All-Ukrainian Scientific and Practical Internet Conference. April 2, 2015). (2015): 95-98. Print.

10. Miroshnichenko A. Delovoe obshchenie (Business Communiction). Moskva: MIEMP, 2008. Print.

11. Reformatskij, A. Vvedenie v yazykovedenie (Introduction to Linguistics). Moskva: AspektPress, 2001. Print.

12. Suhenko, K. Leksichni problemi perekladu (Lexical Problems of Translation). Kiïv: Vid-vo Kiïv. un-tu, 2000. Print.

13. Tatarinov, V. Teoriya terminovedeniya $v$ 3- $h$ t. T. 1. Teoriya termina: istoriya i sovremennoe sostoyanie (Theory of Terminology in 3 Volumes. V. 1. Term theory: History and Current State). Moskva: Mosk. Licej, 2000. Print.

14. Hatrukov, E. Anglo-russkij slovar' po neftyanomu biznesu (The English-Russian Dictionary of the Oil Business). Moskva: "Olimp-Biznes", 2008. Print.

\section{PECULIARITIES OF TECHNICAL TERMS TRANSLATION FROM ENGLISH INTO UKRAINIAN (ON THE MATERIAL OF OIL AND GAS TERMINOLOGY) Svitlana Manhura}

Germanic Philology and Translation Department, National University "Yuri Kondratyuk Poltava Polytechnic", Poltava, Ukraine.

\section{Yana Rudenko}


Germanic Philology and Translation Department, National University "Yuri Kondratyuk Poltava Polytechnic", Poltava, Ukraine.

\section{Abstract}

Background: The paper considers examples of words and phrases that have the same meaning in general language, but change it in a narrow sense, especially in combination with other words. The peculiarities of English terms translation of oil and gas industry are considered. Any professional translator is faced with the need to translate special terms. In order to make the most accurate translation, it is necessary to know the specifics of terms translation.

Purpose: to highlight some aspects of the functioning of vocabulary in the context of oil and gas terminology translation.

Results: The examples in the paper show how important a high level of professionalism is for a technical translator, how important it is to study a special literature and reference materials that are constantly updated to accurately translate technical terms from English.

Discussion: The difficulties of terms translation are mentioned in the article, explaining how to overcome them, should help the translator in achieving accuracy, adequacy of translation. For these purposes it is also necessary to pay attention to the main methods of translation, to know the specifics of the industry.

Keywords: terminology, oil and gas industry, translator, language, translation, knowledge, features.

Vitae. Svitlana Manhura is a Lecturer of Germanic Philology and Translation Department at National University "Yuri Kondratyk Poltava Polytechnic". Her areas of research interests include cross-cultural communication and linguistics, translation studies.

Correspondence: svetmangura@gmail.com

Vitae. Yana Rudenko is a Master's student of Germanic Philology and Translation Department at National University "Yuri Kondratyk Poltava Polytechnic". Her areas of research interests include linguistics and translation studies.

Correspondence: yana.rudenko@oa.edu.ua

Надійшла до редакціії 08 жовтня 2020 року. Рекомендована до друку 23 жовтня 2020 року. 